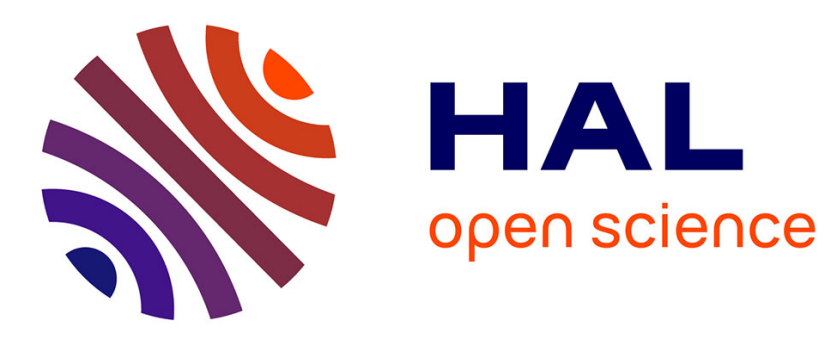

\title{
Drinking coffee, rehearsing civility, making subjects
}

\author{
Alex Jeffrey, Lynn Staeheli, Chloé Buire, Vanja Čelebičić
}

\section{To cite this version:}

Alex Jeffrey, Lynn Staeheli, Chloé Buire, Vanja Čelebičić. Drinking coffee, rehearsing civility, making subjects. Political Geography, 2018, 67, pp.125-134. 10.1016/j.polgeo.2017.09.013 . hal-01790468

\section{HAL Id: hal-01790468 \\ https://hal.science/hal-01790468}

Submitted on 15 Jul 2019

HAL is a multi-disciplinary open access archive for the deposit and dissemination of scientific research documents, whether they are published or not. The documents may come from teaching and research institutions in France or abroad, or from public or private research centers.
L'archive ouverte pluridisciplinaire HAL, est destinée au dépôt et à la diffusion de documents scientifiques de niveau recherche, publiés ou non, émanant des établissements d'enseignement et de recherche français ou étrangers, des laboratoires publics ou privés. 


\title{
Drinking coffee, rehearsing civility, making subjects
}

\begin{abstract}
Alex Jeffrey ${ }^{a}$, Lynn A. Staehelib ${ }^{b}$ Chloe Buire ${ }^{c}$, Vanja Čelebičić ${ }^{d}$
Abstract: This paper explores the role of coffee shops in cultivating youth political subjectivity. It does so through examples of internationally-sponsored processes of state consolidation in South Africa and Bosnia and Herzegovina. We examine how non-governmental organisations (NGOs) have sought to use coffee shops as means through which to cultivate youth citizenship. Reflecting their prominent role in the materialisation of the European public sphere, we examine the significance of civility within these caffeinated spaces, where intimate relations are used as the basis for the consolidation of new political identities. In contrast to those who may dismiss civility as a synonym for political quietism, we argue that the interactions in coffee shops constitute a form of 'intimacy-geopolitics', collapsing the rigid binaries between geopolitics and the interactions of individuals in everyday life. Drawing on qualitative data gathered over eighteen months in both countries we explore how coffee shops act as sites of civility where alternative ideas of political identity — and models of society—may be rehearsed.
\end{abstract}

\section{Introduction}

In a cramped office in a 1960s tower block in a residential part of the Bosnian capital, Sarajevo, the president of a district youth association, Sanela, ${ }^{1}$ recounted activism undertaken by her group to mark the 2013 UN International Day of Tolerance. Gripping a plastic cup and gesticulating beyond the walls of the office, Sanela explained how her group sought to illuminate the social distinctions that cleave Bosnian society using a seemingly prosaic commodity: coffee. The action involved volunteers walking along Vilsonovo Setaliste (Wilson's Promenade, see Fig. 1), a popular pedestrian route beside the Miljacka River in central Sarajevo. Sanela continued:

we offered to passers-by kahva, kafa and kava [different ways of saying 'coffee' often attributed to Bosnian, Serbian and Croatian languages]. So when passers-by said one of the three options we would pour coffee from the same thermos bottle. And then they would ask: "What is the difference?" Exactly, what is the difference? There was so much symbolism about that (interview 30th August 2014, Sarajevo).

\footnotetext{
a The Department of Geography, University of Cambridge, Downing Place, CB2 3EN, United Kingdom.

b The School of Geography and Development, University of Arizona, Tucson, AZ, 85701-0137, USA.

${ }^{\mathrm{c}}$ Centre National de la Recherche Scientifique, Esplanade Arts and Crafts, BP 105-33402 Bordeaux, France.

d The Department of Geography, Durham University, The Science Site, Stockton Road, DH1 3LE, United Kingdom.

${ }^{1}$ All research participants have been given pseudonyms.
} 
Challenging the differences between linguistic signifiers and their signified is a common source of frustration, conflict and amusement in present-day Bosnia and Herzegovina (hereafter $\mathrm{BiH}$ ). But the use of coffee as a means of reflecting the social consequences of these distinctions is neither incidental nor innocent. Coffee plays a central part in both public and private social rituals in $\mathrm{BiH}$, a social role derived from the country's position within the Ottoman Empire between the 15th-20th centuries (Hoare, 2007). In her anthropological study of the nature of 1980s Bosnian village life, Bringa (1995) provides a nuanced picture of the customary role of the 'coffee visit' as a vital mechanism for integrating Muslim and Croat communities within village life. The rituals around coffee drinkingand the attendant conversations, jokes and arguments - underscored a "shared common frame of reference, experiences and a past” (Bringa, 1995, p. 68). It is this commonality that fostered komšiluk (neighbourliness), not as a means through which ethnic difference was erased, but rather a framework through which customary and traditional differences may be reproduced without recourse to violence (see Helms, 2010; see also Jansen, 2015). Coffee, then, was central to the historic cultivation of civility, understood as a set of norms that strengthen social bonds inculcated through repeated embodied practice (Boyd, 2006). The youth group's purposeful illumination of the fragmented coffee nomenclature was therefore a means through which the purported incivility of the present may be brought to the fore.

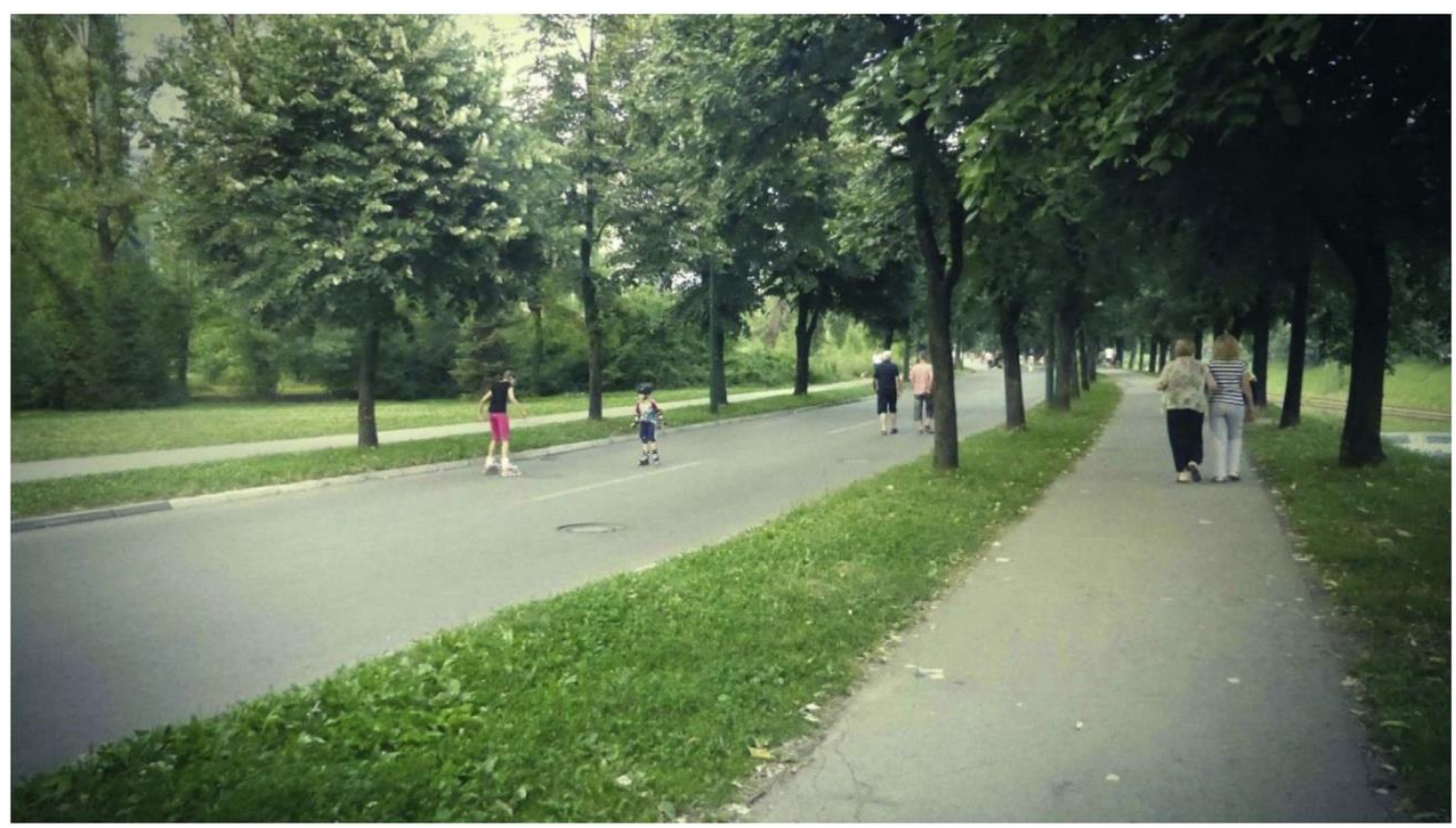

Fig. 1. Vilsonovo Setaliste (Wilson's Promenade), Sarajevo (photo credit: Vanja Čelebičić).

But the relationship between coffee and civility extends beyond the notion of cultivating cultures of sharing and co-existence. In its institutionalisation within the coffee house we can see how the cohesive 
qualities of coffee consumption assume material form within the city (Laurier \& Philo, 2006, 2007). In a second interview, this time in a youth organisation in Cape Flats, outside Cape Town, South Africa, the coffee shop was presented as a site of sanctuary from wider social ills. Coffee here is not a simple stimulant for socialisation, but is rather a more virtuous form of consumption in comparison to illegal alternatives:

So basically the organisation was started to provide healthy alternatives, because at the club what you get there is drugs, it's you know all sorts of rote models ... wrong rote models ... if you want to put it that way ... it's the drug lords that you meet up there, it's alcohol and it's all of those and we just wanted to provide a healthy alternative. So we started off ... the founder started a place off ... as a coffee bar. So while they are selling alcohol and liquor and stuff next door, what you get here, well you walk in here, there's a coffee bar (interview, Cape Town 30th October 2014).

As with the example from $\mathrm{BiH}$, the selection of coffee as the organising commodity for this NGO's initiative should not be overlooked. South Africa's colonial experience has meant that it is tea rather than coffee 2 that is more commonly drunk in both public and private, consequently there is not the social expectation of regular coffee consumption (see Grigg, 2002). Instead, the increased prominence ofcoffee shops is a consequence of the wave of US-style cafe culture that has diffused across gtobat urban spaces since the 1990s (see Smith, 1996). While coffee consumption does not have the same customary role as that of $\mathrm{BiH}$, the coffee shops have emerged in post-Apartheid South Africa as sites of (often elite) consumption, particularly for young people (Pattman, 2007). By emphasising the sanctuary of the coffee bar, the NGO is striving to a create a site where young people may congregate at a remove from the supposed incivility of aspects of the urban environment, whether a justified fear or not (see Lemanski, 2004).

In both examples coffee is entwined with a narrative of sharing - in the Bosnian case shared language, in the South African instance a shared physical space. And in each setting coffee is alluded to as a counterpoint to violence: where coffee provides solace from the symbolic violence of imagined ethnic difference in the case of $\mathrm{BiH}$, coffee is presented as an alternative to the bodily and social violence of addiction in South Africa. The simple conclusion is that coffee is a social lubricant, a means of fostering interpersonal relationships without significant negative health or social consequences. But there is a more significant set of inclusions and exclusions at work, practices that remind us of the political and geographical nature of the exchanges under examination. The creation of spaces of shared

\footnotetext{
2 The type of coffee drunk also varies between the different geographical contexts: in many parts of South Africa instant coffee ('Nescafe') is widely drunk, and while this drink is increasing in popularity in urban $\mathrm{BiH}$, it is still more common to drink espresso-style coffee or coffee made in a džezva.
} 
civility requires pre-ordained moral frameworks, where appropriate forms of conduct are inculcated through familial custom and social mores. The accomplishment of civility necessitates repeated bodily performances that demonstrate the adoption of these norms and mores: the coffee visit must be appropriately completed; the coffee bar must not be sullied by illegal drug-taking. And, furthermore, these sites are not the product of pre-existing social behaviours, but are rather arenas within which such practices are refined and perfected; they should consequently be understood as performative of new forms of social relationship and communal bond. The accomplishment of civility is, then, less straightforward and forces us to think about the forms of exclusion that secure the inclusionary aspects of shared rituals and spaces (see Staeheli, 2008).

Such emphasis on the politics of civility is the focus for this paper. We want to explore how, and with what consequences, coffee shops have been enrolled within the formation of political subjectivity in $\mathrm{BiH}$ and South Africa and, in tandem, the differing conceptions of civility that frame and circulate in such sites. Coffee shops and coffee drinking became tools that sought to promote rather diffuse and dynamic performances of political subjectivity, at times as an individualised political subject and at others a member of a collective identity. While the prominent position of the coffee house as an abstract example of the development of the European public sphere in the eighteenth and nineteenth centuries is well established, we are interested in the specific - and varied-enrolment of coffee shops as a means of claiming, legitimising and enacting new forms of political identity. In doing so we are contributing to recent geographical work that has focused on the materiality and embodiment of geopolitical discourse, specifically from a feminist perspective (Mountz \& Hyndman, 2006; Pain, 2014). For example, emerging work in the field of intimacy- geopolitics has drawn attention to the significance of intimate embodied encounters as performances of geopolitics, challenging longestablished binaries of local/global, material/embodied, fa- milial/state (Pain \& Staeheli, 2014; see also; Harker \& Martin, 2012). Orientating the discussion around coffee shops provides a sense of the quotidian spatiality within which practices of identity formation unfold, tracing lines between purportedly transnational geopolitical projects of state formation with highly localised and intimate practices of consumption, discussion and co-existence. This is not, then, simply a study of the formation of political identities framed by the backdrop of coffee shops: it is not a study of geopolitics writ small. It is instead an exploration of how the imaginaries, materials and practices of coffee shops perform a series of political functions of enclosure, providing sanctuary from wider social cleavages, and embedding norms of citizenship.

Central to such sites, as intimated above, is the notion of civility, where civility is not a synonym of quietism, but understood instead as a form of political intervention where a more hopeful style of 
politics is prefigured in the present. In doing so we are keen to contribute to geographical debates regarding the normative framing of civility, exploring how certain kinds of behaviour and comportment are understood as 'civil'. Like others (see Boyd, 2004, 2006) we are interested in the extent to which civility can be understood as a set of rules, shed light on questions of authority, and be learnt in social settings. Illustrating the politics of civility demands close attention to the microgeographies of political practice, where organisations and individuals bring into being sites of deliberation where alternative models of social life may be rehearsed. In this sense the civility can be understood as a form of intimacy-geopolitics, where the distant with the intimate are entwined as rules are reproduced through embodied practice. One of the tasks, then, is to examine the emergence of politicisation: the moments, sites and practices through which politics is enacted. By foregrounding intimacy-geopolitics we are seeking to challenge an image of civility as a catalyst towards a postpolitical era, where "contention, or dissensus, particularly over fundamental ways of seeing, knowing and understanding the world, has been quieted through a consensus built among 'stakeholders', or those already presumed to have a stake in the existing order of things" (Mitchell, Attoh, \& Staeheli, 2015, p. 2). In particular, we share with Mitchell et al. (2015) the desire to broaden the concept of what counts as politics and how consent and civility may be understood as avowedly political acts. This approach involves challenging the emphasis placed on violence and antagonism as the dominant social product of post-politics (Mouffe, 2005; Zizek, 2008), to think instead about the particular acts, dispositions and styles of comportment that disrupt conventions, forge solidarities and enact alternatives. In this sense, even pouring coffee from a thermos on a tree-lined boulevard is a style of intimacy-geopolitics (see Pain \& Staeheli, 2014).

With the aim of exploring actual-existing cultures of civility we are using examples drawn from comparative work conducted in $\mathrm{BiH}$ and South Africa. This comparison is not straightforward, as these two countries have different historical experiences of political upheaval, democratic transition and manifestations of the public sphere. But over the last two decades both have been sites of intense international intervention to consolidate the state, whether in the wake of Apartheid division in South Africa (McEwan, 2003; Staeheli \& Hammett, 2013; Wilson, 2001) or the violence of the conflict and its aftermath in BiH 1992-5 (Jeffrey, 2013; Toal \& Dahlman, 2011). Such interventions have been specifically directed towards the cultivation of new forms of civic citizenship, styles of belonging, solidarity and membership that are intended to transgress lines of racial or ethnic difference. While these initiatives have taken different institutional forms in $\mathrm{BiH}$ and South Africa they have invariably set upon a specific demographic: youth. In both contexts, young people have been central to the operation of state building interventions, viewed as future citizens who could correct—or overcome- 
the divisions that have riven society in the past and present (see Jeffrey \& Staeheli, 2016). It is tempting to view such a focus in instrumental terms, to see young people as the instigators of a future civic citizenship in sites where accounts of separation have dominated formal political discourse. But in line with the feminist perspective of the paper we are resisting an instrumental understanding of the exercise of geopolitical power projected from international agencies 'down' to young people in particular social contexts. Instead we are seeking to focus on young people's reception of programmes designed to foster new political subjectivities through which we can glimpse the solidarities that youth might imagine, strive for, stabilise or seek to change.

Methodologically, this paper draws on eighteen months of residential fieldwork conducted simultaneously by the research team in $\mathrm{BiH}$ and South Africa, interviewing over 150 members of youth associations, schools, governmental agencies and international organisations. The interviews were conducted in the language preferable to the interviewees and later translated to English, a process that involved the researchers checking for meaning with the research participants and discussing the challenges of translating terms such as 'citizenship' and 'youth' across cultural settings. The research was orientated towards exploring the production and performance of youth citizenship in contexts that have experienced rapid — and socially-divisive — political change. We were particularly interested in the spaces within which youth citizenship was formulated and lived, and as outlined above this has drawn attention to the role of coffee shops and coffee drinking as practices that necessarily entwine the political with the recreational. Reflecting their prominent role within these processes, the research focused on the actions and intentions of non-governmental organisations (NGOs) in both countries, employing participatory approaches that included seminars, workshops, exhibitions and digital story telling. In the discussion that follows all individuals and organisations have been given pseudonyms. The scale of the project allowed for an avowedly mixed methodology, one that traced the institutional networks of NGOs, donors and intergovernmental organisations alongside a concern for the agency of individual embodied actors within these wider material and immaterial frameworks. One of the recurring institutional dynamics across the sites has been the prominence of discourses of civil society, both as an organisational context for the cultivation of youth citizenship but also as a normative ideal. So common have been the invocations of civil society that they can fall into the background, become a placeholder for a range of agencies or political projects. But in this paper, we are seeking to argue for the utility of re-examining civil society as both a concept and a set of political practices. For us, exploring civil society means scrutinising how civility is understood and practiced, work that forces us to reengage with questions of embodied politics, the nature of propinquity and the role of intimacy in shaping political communities. 
The paper is divided into four further sections. In the first we explore the relationship between civility and coffee houses, tracing their historical relationship and teasing out key distinctions in the social position of coffee drinking. In this discussion we are concerned to emphasise the ambiguities that lie behind claims to civility, articulations that mask normative concerns for the structure and purpose of society. The second section examines how we need to embed the emergence of coffee shops within specific processes of state formation. In both empirical contexts the novel geopolitics of the state has implications for the role of coffee shops. For example, in $\mathrm{BiH}$ they have, at times, become mechanisms through which individuals will perform (and challenge) ethnic identifications, while in South Africa, by contrast, the pace of post-Apartheid democratisation has led young people to call for sites where democratic politics may be deliberated beyond the home and the street. In both we see a tangible expression of intimacy-geopolitics, where the putatively geopolitical is, in fact, imbricated and intertwined with the interactions of subjects in the coffee shop. The third section develops these initial observations by examining how young people established coffee shops as sites to practice new forms of civic identity, shielded from some of the more destabilising social forces (variously understood as drug abuse, nationalist politics, corruption or illegality). These accounts illuminate the spatial qualities of the coffee shop as something distinct from other arenas, in particular that of private or public space. The coffee shop became a secluded site of rehearsal, where new forms of political and social identity could be performed. Finally, in the fourth section we examine coffee shops as sites of place-making, where civility stems not merely from inter-subjective exchange, but from the connection forged between these practices and the place itself. The coffee shops, amongst other sites, became entangled in expectations over behaviour, for example acting as a team, being creative or keeping the place clean. These mundane spatial factors were not mere backdrops to the practice of subject formation; they are constitutive of intimacy-geopolitics, political subjectivity, and state formation.

\section{Civility in the coffee house}

History is replete with examples of the consumption of coffee as a social stimulant, coupled with desires by those in authority to limit consumption through either outright prohibition or limiting access to where coffee may be consumed. Some of the earliest references to this role come from the Ottoman Empire, where coffee was consumed by Sufis to combat exhaustion following long nights of worship, though this stimulating effect led to coffee being banned by Islamic religious leaders fearful of its potentially socially-degenerative qualities (Kömeçoğlu, 2005). However, the popularity of coffee as a social drink across Ottoman lands - coupled with the strict prohibition on the consumption of alcoholic 
drinks - led to the migration of coffee drinking from the religious to the secular domain. As Kömeçoğlu (2005: 8) explains:

[c]offeehouses transformed urban life, changed patterns of social interaction, introduced a new process of socialisation, and rearranged urban spaces. The coffeehouse created a viable public space for patrons, who were socially restricted by the privatising effects of the home, the residential quarter (mahalle), and the dervish lodge (tekke).

The subsequent role of the coffee house as a reflection of - and central to - the constitution of a public sphere in Europe is well known (Habermas, 1989). For Habermas (1989), the tischgesell- schaften (table societies), salons and coffee houses of eighteenth century Europe ushered into existence new conventions on social intercourse and morality. Habermas identifies three traits held in common across these varied social sites: first, they promoted a bourgeois public sphere where tact tookpriorityoverovert displays of social rank; second, public debate called into discussion arenas that until then had been the sole interpretative domain of the church or state authorities; and, finally, they were conceived as open and inclusive, at least in principle (see Habermas, 1989, pp. 36-37). This was purportedly a public sphere structured around the exercise of reason, not simply in terms of art, culture and science, but a public able to reflect on its own existence and purpose.

Despite these high purposes projected on to 'the coffee house' Habermas's account suffers from a lack of spatial engagement, either in terms of engagement with real-life examples of coffee houses, the embodied nature of coffee house patronage, or the absence of a global vision that accounted for the transnational patterns of commerce and oppression that produced such landscapes of consumption (see Bartolovich, 2000). Habermas's account is, as Landes (1988) makes clear, a masculinist image of a bourgeois public sphere, writing out the presence and perspectives women, normalising gendered hierarchical relations while also conveying a sense of detached objectivity. Laurier and Philo (2007: 268) note Habermas's imagined relegation of social standing, political influence and economic power, each "dismissed from the historical public sphere as irrelevances [...] in that the force of the superior argument was all that would "carry the day"'. Of course, such faith in the persuasive force of rational debate overlooks the socially- coded mechanisms of exclusion stemming from intersecting identitymarkers, such as class, gender or race (see Howell, 1993; Landes, 1988; Marston, 1990). In tandem, the central role played by the coffee shop in Habermas's history of the public sphere presupposes already 'civilised' bodies engaging in discourse and deliberation, that the coffee house allows a site for the performance of already-existing social relations, rather than a site of experimentation.

Dean (2001) contrasts the Habermasian coffee house with the exploration of the salon as a public space in Benhabib's (1995) essay The Pariah and Her Shadow, a study of Hannah Arendt's biography of 
Rahel Varnhagen. Dean draws out a feminist critique of the apparent inclusivity of Habermas's vision of the coffee house, exploring instead the styles of exclusion, social performance and identity formation that were inherent in the operation of the salon:

[t]his is precisely what Rahel Varnhagen's salon was: a space of sociability in which the individual desire for difference and distinctness could assume an intersubjective reality and in which unusual individuals, and primarily, certain highly talented Jewish women, could find a "space" of visibility and selfexpression [...] [T] he salons forged bonds across classes, religious groups, and the two sexes, creating the four walls within which new forms of sociability and intimacy could develop among members of an emergent civil society (Benhabib, 1995: 17; see also; Dean, 2001).

This vision of intimacy and experimentation of social expectations orientates attention to three intertwined aspects of the coffee shop/tischgesellschaften/salon. First, it constitutes a site set apart from either 'private' or 'public' space, comprising a mediation of the two, where aspects of comportment, behaviour and address maybe rehearsed. While rejecting elements of Habermas's account of the public sphere, this positioning emphases an avowed separation between the civilityof the c ee house and the "unruly territory" of the street (see Laurier \& Philo, 200 ,p.266;Smith, 1996). Second, the coffee shop constitutes a site where political subjectivities may be forged, that is, where interactions with others facilitates the learning of new political subjectivities (see Jeffrey \& Staeheli, 2016; McConnell, 2016). Third, these varied accounts illustrate the differing social dynamics of civility: as a facilitator of social intercourse governed by rules of tact and reason, while also a site of experimentation, exclusion and identity formation.

However, there is a danger that by exploring the production of political subjectivity within the coffee shop we sidestep wider historical geographies of civility. When considered less as a social practice and more as a relational identity (in contrast to incivility or barbarism), civility has a chequered past. It conjures images of the 'civilising mission' of Western seaborne colonial states, wrapping their imposition of exploitative governance and violence in the virtuous gloss of higher moral behaviour. Of course, such accounts are indebted to the critique of Orientalism (Said, 1978), work that illuminates the co-production of civility and incivility as a structuring narrative that enabled more pernicious and intrusive forms of international intervention (in the past as well as present, see Gregory, 2004). Consequently, the very language of civility (like 'development') is loaded with an unpalatable normativity. As Claire Mercer (2002: 11) states "the assumption is that civil society (in its familiar western guise) has somehow gone wrong in the developing world; that these societies are incapable of becoming civil." Scholars have traced such assumptions within interventions in both South Africa and $\mathrm{BiH}$, where external agencies have justified their practices on account of their external nature, that they can transcend local affiliations while imposing transnational values of human rights and 
democratisation (Belloni, 2001; Fagan, 2005; Hearn, 2000; Jeffrey, 2007). What can be taken from this work is an underlying scepticism as to the reality of 'civilising' narratives, or that such narratives fail to grasp the true power relations that stalk the practice of intervention.

While this is a significant observation of the continued operation of colonial forms of knowledge production, it does not mean that civility itself is always a governmental practice, a practice that has winners and losers. In recent work, Boyd (2015) has sought to make a clear distinction between the kinds of rule-based social norms characterised by the concept of justice, with the role of civility, which he equates, following Adam Smith, to a notion of 'style'. For Boyd (2006: 864), civility has both formal and substantive attributes: it emphasises sets of customs and behaviour while also gesturing at an individual's standing within a political community. Necessarily, then, civility is always plural as the codification of behaviour is collectively established and reinforced. In this way-and this is Boyd's point - civility is a form of minimal moral obligation within a political community where forms of political or ethical consensus are not possible. Mirroring ideas of agonism (Mouffe, 2005) or politics of propinquity (Amin, 2004), civility is thus a term that draws our attention to habits through which difference may be accommodated within a moral and political arena, it focuses our attention not so much on the bodies themselves but the nature of the spaces and intimacy between agents. In doing so it centres on the distance between social actors, the material and immaterial networks within which they are embedded, the forms of affect that shape the constitution of place and, most crucially, the styles of respect and empathy that can be fostered through associative life. Hence, political contestation is not necessarily inconsistent with civility, if debates and actions are conducted within socially recognized and validated limits, for example with a commitment to non-violence or with empathy for the desires of immanent others.

Grounding civility-as-style in specific social contexts requires the reinsertion of the coffee shop. The first empirical point is that coffee shops take multiple forms. We are not interested in the abstraction or ideal-type but are thinking instead of how these institutions are manifest within specific urban landscapes. But the immediate challenge to such empirical pragmatism emerges from the mediation of coffee shops through the lens of specific multiply- positioned actors and, considering the different social histories of $\mathrm{BiH}$ and South Africa, attitudes towards coffee shops varied widely between the case studies. However, across the two sites we began to trace common understandings and uses for coffee shops, where NGOs draw on the coffee shop precisely for their connotations as sites of civility and political subject formation. At first glance, this is a story about spaces and their appropriation into political discourses. In $\mathrm{BiH}$, coffee shops have-in certain circumstances-become enfolded into narratives of ethnic difference. But in South Africa the implications of state formation have been 
different: here coffee shops have been actively promoted by some young people as sites through which to deliberate new political identities. The second interpretation of coffee shops extends this spatial storyline to think about the ways in which they can be understood as sanctuaries, that is, detached from-but influenced by - their surroundings. In both $\mathrm{BiH}$ and South Africa, this status as neither public nor private space was utilised as a mechanism to forge new political and economic identities, a safe space to rehearse forms of political subjectivity that may be enacted in wider society at a later date. The final interpretation of the coffee shop is as place-making: sites that are not simply detached from wider society but are attempts to prefigure alternative political communities in the present.

\section{Coffee shops and state formation}

The varied imaginings and uses of coffee shops in $\mathrm{BiH}$ and South Africa illustrated some key dynamics in processes of state formation. In the case of $\mathrm{BiH}$, initial questions regarding coffee shops, to both NGO members and administrators, would often be met by a smile and suggestion that these were sites that illustrated the indolence of young people. Some NGOs were even trying to actively challenge the entwining of young people and coffee:

We have attempted to present a positive model of a young person, that not everything is nationalism, cafes and Facebook (youth association leader, Sarajevo 8th June 2014).

As the interview excerpt above exemplifies, the practice of drinking coffee was often allied to other characteristics, whether a nationalist political outlook or a dependence upon social media. Entwining nationalist politics with coffee drinking points to the potential incivility of coffee shops, where single sites may pose opportunities for deliberation, but as a set of differentiated spaces could cultivate exclusion. The dominance of ethnic frameworks within post-Dayton $\mathrm{BiH}$ is such that there are almost limitless socially-coded ways of demonstrating membership with an ethno- national group, indeed the more common refrain is the inability to perform a civic 'Bosnian' identity when choices of consumption, residence and language (amongst others) portray ethnic affiliation (Toal \& Dahlman, 2011). Consequently, members of NGOs and youth associations would remark-or more often lament - the imprint of ethnic difference onto the landscape of coffee houses, though these distinctions pre-date the Dayton Agreement (see Helms, 2010; Jeffrey, 2013).

But the research illuminated the considerable agency of NGO activists in subverting this ethnic matrix reflected in the coffee shop landscape. In one case an ethnically-mixed NGO from the divided town of Stolac would always plan their activism in a coffee shop, deliberately selecting nationalistic cafes where their group presence would challenge expectations of identity and belonging. Their intimacy and civility with one another served to challenge the geopolitical scripting of Bosnia as an ethnically 
divided territory (Campbell, 1998). In another case, a member of an international NGO described how part of their activities would involve touring purportedly 'divided' towns with group of young people who variously identified themselves as either Croat or Bosniak (Bosnian Muslim). The NGO member would ask the members in which part of a particular town they felt comfortable drinking coffee, leading to contestation amongst the young people as to where was the most appropriate place to sit and drink. Part of this performance - and echoing the action that opened the paper-was to point to the illusory nature of the imagined distinction between these sites. "So we would have two coffees," the project leader remarked, "the first one on one 'side' and the second one on the other 'side"' (interview, Sarajevo 16th July 2014). Of course, reproducing the sense of difference (that two coffees were required) is a minimalist challenge to the notion that coffee drinking can denote ethnic affiliation. Extending Benhabib's (1995) notion of the salon as a site of identity- formation and experimentation, coffee houses were not simply social spaces where identity may be performed, but were rather sites where the very selection of a coffee house would pre-suppose ethnic affiliation.

But in the South African context there was an alternative narrative of the relationship between coffee shops and processes of state formation. Rather than viewing the coffee shop straightforwardly as a part of the wider dynamic of the post-Apartheid state, young people were developing coffee shops as deliberative sites within which to consider their own role in creating new political subjectivities. For example, one youth leader talked of the need for deliberation and the need to connect democratic participation with everyday life in South Africa:

I think we have to be the generation that learns how to live in a democracy, that actually learns how to do it because the generations before were so grateful for it, and it's so great that they should have been grateful for it. But they were grateful for it and then they thought it was some kind of silver bullet, panacea kind of thing. It arrives and stuff happens. Now we are learning that stuff doesn't just happen. Living in a democracy is an everyday thing (interview, Pretoria, South Africa, September 21st, 2014)

In part it reflects a particular historical moment in the development of South African democratisation, where numerous organisations spoke of an arc of political activity within civil society organisations that peaked with the end of the Apartheid (1994) and has struggled to be reasserted in the years since, as either funding for NGOs has reduced or individual activists have taken roles within institutions of government (a process explored by Hearn, 2000). While there was some concern expressed by organisation leaders that action in civil society seemed to be quieted and perhaps redirected away from the state in the post-apartheid period, the organisations themselves identified ways in which they could intervene. These interventions often seemed to be directed at individuals, and so were quite different to the structural changes demanded through the Liberation Struggle. The protests of recent years demonstrate that there is a great deal of activity, but it often seemed unfocused and was not recognized 
as being the 'right' sort of activism by many civil society organisations (Buire \& Staeheli, 2017). Equally important, however, activists and organisations argued that there were spatial barriers, and expressed a desire for sites where such deliberation could be enacted on their own terms, as explained by a representative of a rights-based NGO:

[...] with '94 and pre- '94 and the Truth and Reconciliation Commission (TRC), there was a lot of emphasis on talking - and then all of a sudden it was just like, okay, we don't really have to talk anymore we now just have to do, we need to do. So it feels like for the past 20 years we've been missing out on talking really. So that's why with this project I see more and more how important it is just to have a space to talk and to see (interview, Cape Town 4th November 2014).,

Where BiH coffee shops were identified by some as sites for the performance of ethnic identity, in these examples we see the value placed on coffee shops as sites of propinquity cultivating Habermas's (1989) sense of the public sphere, where proximity, regular interactions and acknowledged social rules lead to the possibility of debating public affairs. But the key distinction within these examples relates to the spatiality and temporality of political subject formation: as opposed to Habermas's sites where preexisting civilised bodies would come together to discuss public affairs, these examples point to the construction of sites as loci of identity formation, and the performance of new forms of deliberative citizenship.

\section{Coffee shops as sanctuary}

If coffee shops were criticised for entrenching ethnic understandings of identity in $\mathrm{BiH}$, drinking coffee was also attached to a sense of abrogating responsibility for their future:

You know, you will see a lot of young people, drinking coffee, unemployed, still waiting for someone to solve that problem. And that's something we are really trying to change. It's very difficult (programme manager of a youth network, Sarajevo $1^{\text {st }}$ July 2013).

This sense of coffee drinking as 'waiting' was called upon to illustrate specific moments where young people failed to participate in ongoing protests or activism. For example, the president of a youth activist group lamented the participation of her peers in the 2013 protests over birth registration in $\mathrm{BiH}$ :

I went to the shopping centre [...] and there was a lot of young people sitting there drinking coffee. Also, the protests we had before, it was at the main square here in Tuzla, we were standing there and people are sitting at the cafe drinking coffee and juices. Then on Sunday [...] there was actually one girl who died, and we had, like we bought candles and we wanted to, we gathered late at night around 9 o'clock and there was 5 minutes of silence, and stuff, so like the local cafes turned down the music, and I was 
expecting that the people would come out. No. They just sat and they waited and then when the music went up they just continued (interview, Tuzla 2nd July 2013).

This image of the intertwined nature of coffee drinking and youthful indolence or misadventure has a long lineage, Bringa (1995) explores in ethnographic detail the central role played by coffee houses as sites for matchmaking and dances in 1980s Yugoslavia. As the youth association leader outlines at the start of this section, part of the objectives of many youth advocacy NGOs related to dispelling this image, either by illustrating the many activities that engaged young people beyond the coffee shop, or rethinking the activity of drinking coffee (and socialising) in less pejorative terms. Reflecting the high levels of youth unemployment in both $\mathrm{BiH}$ and South Africa, the centrality of coffee drinking to young people's lives reflects a wider global labour market change, where the jobs that would have previously occupied these young people do not exist (Lippman, 2014; Posel, Casale, \& Vermaak, 2014). In this sense, the presentation of coffee drinking as indolence is itself a legacy of an assessment of social worth (especially amongst the imagined 'bread-winning' men) based on productivity (see Ferguson, 2015). As we shall see in the examples under examination, social understandings of value and worth are not so straightforwardly aligned with productivity in contemporary BiH or South Africa, where individuals seek to develop networks, skills and forms of deportment that enable participation in both paid employment but also as social and political actors. In this sense - and reflecting a key argument of the paper-coffee drinking may not be simply an outcome of a disempowered youth passing "surplus time", but rather be understood as a means through which social skills and connections are refined while waiting for future opportunities, whether social, political or economic (see Jeffrey, 2010). But at some moments in the research the link between productivity and coffee drinking was more explicit. As part of the research we conducted participant observation within Urban Coffee Hub (UCH), a social space in Cape Flats outside Cape Town that combined a conventional cafe with educational and training events. This research method involved running workshops within the cafe, alongside frequent visits and interviews with members, employees and visitors. As a government official responsible for providing funds for $\mathrm{UCH}$ explains, the initiative was designed in order to motivate young people both within and beyond the walls of the cafe:

[the] Youth Cafe is partly modelled on the Norwegian type of youth cafes where young people can come together, have access to internet, $\mathrm{WiFi}$, be connected to what's happening within society. And then from there they get linked to organisations where they do certain things. For example, ifyou're an excellent athlete the Youth Cafe will be able to link you to where is athletics being done (interview, Cape Flats 26th August 2014).

This imaginary of connectivity captures the networked nature of civil society in both South Africa and $\mathrm{BiH}$, where information and contacts becomes vital for participating in associative life (see Marshall 
\& Staeheli, 2015). The desire to cultivate entrepreneurial subjects sat alongside a sense of creating a community, articulated as a new style of identity or belonging. As one of the founding members explained:

[it] doesn't matter if you are Christian or Muslim or Buddhist or ifyou don't believe in any God or you believe in African tradition or whatever, that's irrelevant. [...] And very soon people realise that when you become part ofUCH unfortunatelyor fortunately, it depends on how you look at it, it just becomes a part of who you are. You don't lose your identity but the identityofUCH very soon gets attached to you as a person and people see you and they say, hey, there's Sophie from UCH, it's always Sophie from $\mathrm{UCH}-$ they see you and they see this good thing that you're doing and they attach that with UCH. And it has become a good thing for people because now people are accountable (interview, Cape Flats 18th September 2014).

This sense of identity formation differs from the ethnic- inscription on the landscapes of coffee houses in $\mathrm{BiH}$. The approach of $\mathrm{UCH}$ is more akin to branding, where participation is understood as constituting group membership. As the excerpt suggests, this is not an attempt to connect the activities at the cafe to wider national or religious identifications, but rather to stabilise a sense of solidarity within the institution itself.

The second implication of understanding the coffee shop as a sanctuary relates the possibility of selfimprovement. The cafe ran a series of (largely ICT-related) workshops and seminars, events that earned participants credit within a virtual currency which could be spent on a restricted set of goods within and beyond the cafe. Each day the available workshops and activities would be listed on a blackboard beside the coffee machine and take place in seminar rooms attached to the cafe (see Fig. 2). By foregrounding the entrepreneurial nature of the workshops the cafe could come across as a business incubator, indeed one of the founding members of the organisation saw the cafe's activities in these terms:

\footnotetext{
And it's a very informal thing and you come up with a verycrazy idea about how you can address that situation - and, they're, okay, let's talk about that, let's explore that some more. And we give people training on our entrepreneurship. We have an innovation incubator, an accelerator. And it's just for social enterprises, the business has to have a social impact, it has to be scalable and it must have a business model (interview, Cape Flats 18th September 2014).
}

Through this lens the cafe does not cultivate civility, understood as a set of minimum moral obligations in Boyd's (2006) terms; rather it looks to be cultivating the appropriate social and cultural capital in order to become entrepreneurial and self-managing citizens. Such neoliberal interpretations of citizenship — where civility is paired with competence within a free market — were evident in a number of youth development NGOs in both contexts, such as this organisation in Sarajevo, BiH: 
[b]ecause our definition of empowerment would be, that you have young people that are not marginalized, that are not out of the job, and that are active in society. And so, you cannot be active in society and at the same time be poor and out of the labour market. So I would say that, somehow, it goes together (interview, Sarajevo 1st July 2013).

The enduring sense of productivity is at the heart of meaningful social membership and civility. Here 'inclusion' is judged solely in terms of the labour market, and participation in youth citizenship programs - such as the youth cafe — is measured in terms of future employability; participation - the hallmark of active citizenship — seems not to be a social good in itself. The political outcome of such a normative image of participation is the fostering of acquiescence. Indeed, during an observation of a $\mathrm{UCH}$ workshop a participant was rebuked by the convenor for suggesting that the challenges young people faced in South Africa were 'systemic' rather than a consequence of a lack of individual action (field notes 31st August 2015).

These accounts point to an understanding of civility that remains haunted by an expectation of certain forms of comportment and consent, potentially draining the term of a transformative potential. In these instances, there appears a political economy to civility where adherence to externally-imposed rules carries a higher social value than exploring alternative models of social order. Reminiscent of the criticisms of Habermas's bourgeois and Eurocentric imagination of the civilised public sphere, these insights reproduce a sense of the coffee shop as a site of neoliberal work and subject-formation. Unquestionably this sits at odds with more progressive expectations of the such sites, but it valuably illuminates the simultaneity at work within rehearsals of civility: where intimate exchanges can be both stabilising neoliberal imaginations of work while also producing sites of encounter that can unsettle practices of state formation. 


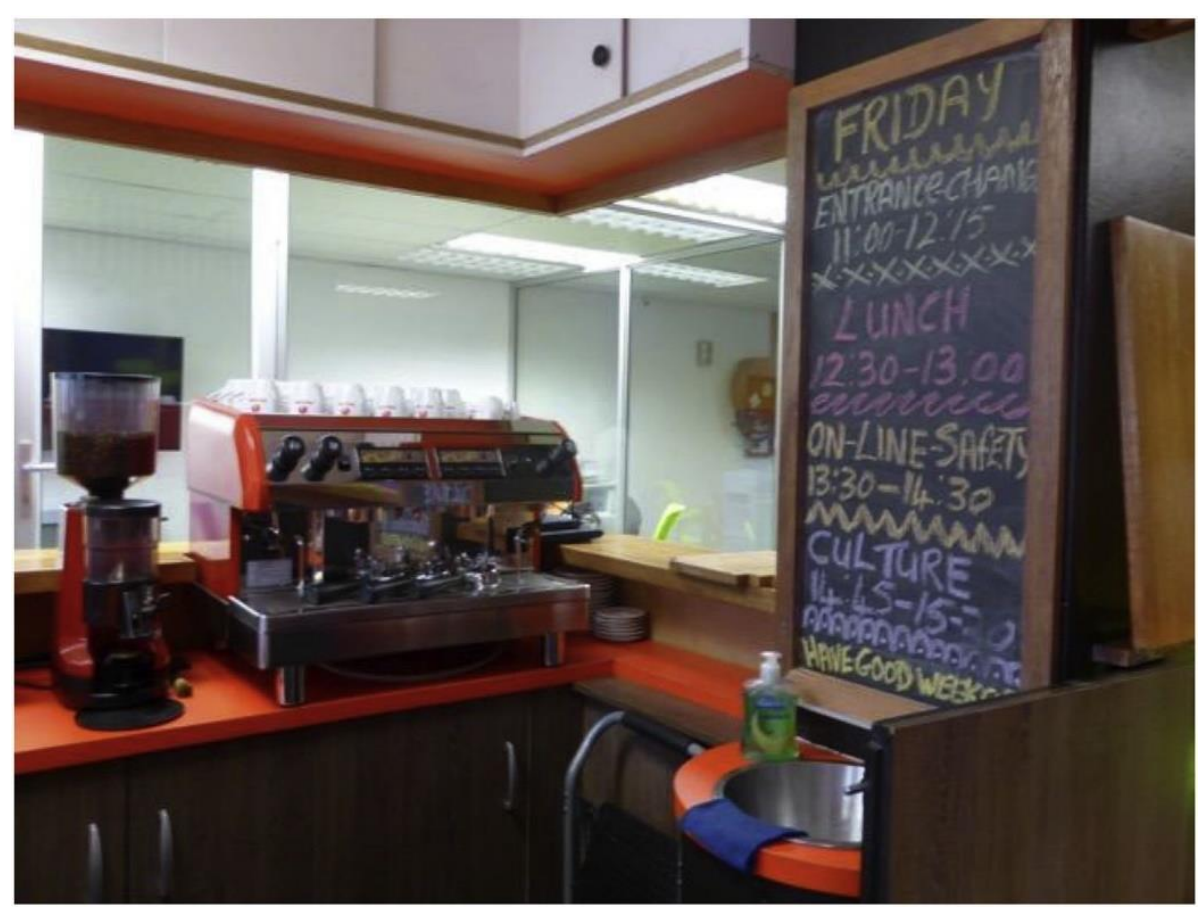

Fig. 2. Urban Coffee Hub, Cape Flats (photo credit: Chloe Buire).

\section{Coffee shops as place-making}

These rather static performances of identity deviate some distance from an understanding of civility structured around the negotiation and accommodation of alterity, and there seems little left in this account of the shared experience of social difference played out in the Bosnian coffee visits discussed earlier in the paper (see also Helms, 2010). But observing the practices unfolding within the UCH often challenged these images of either the entrepreneurial subject or a static understanding of identity. The space of the cafe acted as a site for young people to gather that was neither on the streets nor cost money. There was a loyalty to the space and its usage that led to contestation over the appropriate forms of behaviour or comportment within the cafe. For example, after one workshop session most participants filed out of the seminar room, straight through the cafe and onto the streets. This animated Chris, a program manager working with the NGO which runs the cafe, who felt that they were not participating appropriately in the life of the cafe:

I saw Chris standing up from his chair overtly upset. "This is what I don't like," he said, and then explained: "They only come for the session and they don't stay." [...] To me, this is also an example of the invisible expectations that come with the cafe, so invisible and untold that they might not even have been shared by everyone (field notes 26th August 2015).

This brief exchange directs attention at a number of issues at the heart of this paper: that there are certain unwritten codes of behaviour within the space of the cafe; transgression defines the individual as an outsider. Status, in these terms, is derived from behaving in a way that is consistent with the 
norms established by the wider group, where tact takes place over social rank (to make a direct connection with Habermas). Perhaps most crucially, and entwining both of these points regarding civility, the excerpt reveals the underling geographical significance of these processes: the street is not the same as the cafe, and the cafe holds value as a distinct and separate place.

The comments above, supported by observations of the operation of the cafe, point to the significance of being-in-place as central to the creation of civil public sphere: it is not the structured workshops that produce the sense of identity but rather the experience of being together within the cafe. Proximity and intimacy are productive of (largely) sub-conscious rules that govern the insider/outsider distinction. We found similar accounts in $\mathrm{BiH}$, where drinking coffee together constituted a moment of productivityand collusion, as a counterpoint to the more instrumental and formulaic 'professionalization' of NGO life. As one project manager remarked in reference to the early days of running their youth NGO:

At that time we had the most activities and we were keen to do anything. At that time we used to consume one kilo of coffee in our office, as many people used to visit our office we used to drink one kilo of coffee per day. They all come, take a cup of coffee and work on something. We played cards as well, we had fun, but we used to have over one hundred projects. And then we started trainings, management, and introduced a new system. Until then the things were chaotic (interview, Brcko 17th September 2014).

There is a narrative arc in these comments - and in the disposition of the interviewee as he delivered them-between the playfulness of the early coffee-driven days and the growing bureaucratisation of the project as increasing managerial instruments shaped the NGO's activities (see Baillie Smith \& Jenkins, 2011). It would be tempting to see a clear distinction between the intimate and improvised civility of the early days of the organisation, juxtaposed with the instrumental understanding of civil society conveyed more recently. But instead we want to think of the continuities across these activities, that the solidarity and sense of belonging fostered in the early years of the organisation are embodied in the membership and endure to the present, there is no clear break or distinction. Rather than seeing the formalisation of their activities as a hollowing-out of its transformative potential, we should see it instead as its wellspring.

\section{Conclusion}

While coffee has a long history of serving a social function, it also has an intricate geography. In its materialisation in the coffee shop there has been a long running interest-from cultural geographers, anthropologists and sociologists - in the role of such spaces within social rituals and the production of the public sphere. In this paper, we have sought to examine the political geography of coffee shops, in particular the ways in which they have been used by NGOs to stabilise certain understandings of 
political subjectivity, in both individual and collective terms. Partly this objective stems from the prominent role granted to coffee houses within established accounts of the emergence of the European public sphere, but it also has a more mundane origin: the prevalence of coffee shops and coffee drinking within the context of efforts to foster youth citizenship in post-Apartheid South Africa and post-conflict $\mathrm{BiH}$. This argument has been set within two (entwined) theoretical frameworks. The first is the field of feminist geopolitics that seeks to trace the embodied and situated nature of geopolitical practice, not simply as an elite discourse that is transmitted 'down' through imagined spatial scales, but rather one that is entwined with, performed in, and constituted through the intimacy of everyday encounters. The second is a desire to challenge a view of these forms of civil encounter as a reflection of post-politics, where such forms of practice may be rendered as acquiescence to hidden neoliberal forces.

Three conclusions stem from this argument. The first, and perhaps most instrumental, relates to the varied and significant role played by coffee shops as sites of political subject formation in both $\mathrm{BiH}$ and South Africa. At a time when cultural and economic geographers are paying increased attention to the economic role of co-working sites within cities as flexible alternative to the rigidity of the office (see Lange, 2011), so coffee shops are performing a function as neither home nor public space in these two case study countries. We must be careful here not to reify the coffee shop as a stable backdrop, instead understanding the mutability of this spatial designation; we saw in the final section how certain sites can assume elements of the 'coffee shop' (an NGO office for example) only to change meaning and purpose over time. The evidence points to a socially-mediated set of practices of inclusion and exclusion, where minimal rules of membership emerge - as compared to derived from - the legal fundamentals of citizenship, but in terms of behaviour, outlook or willingness to participate in conversation. But just as a co-working space may signal a profound shift in the geography of productivity, so the significance placed on coffee and coffee shops may point to differing processes through which solidarity and subjectivity are formed. In neither setting were coffee shops spaces of overt formal political debate, but were rather sites where minimal aspects of shared existence were negotiated. For example, conversation may not focus on normative issues of state policy, but who are the 'we' that frame deliberations of the state's existence. Other embodied elements of political practice became significant: proximity, comportment and shared experience.

It is this point regarding the embodied nature of interactions that orientates attention to a second conclusion; namely that we have emphasised the significance of these mundane sites to the operation of politics. We are specifically seeking to challenge the centrality of antagonism to accounts of the production of political subjectivity, emphasising instead the significance of prosaic repetitions of 
cultural practices as the origin points for new senses of belonging. Of course, an emphasis on the significance of communality and consensus to the operation of politics has been an enduring refrain of feminist scholars, where the binary between the grassroots activism and the state has been questioned in numerous ways (see Koopman, 2011, for example). We want to contribute to this work by examining coffee shop interactions not as 'anti-geopolitics' (romanticising a grassroots actor striking against the agents of geopolitics) nor as a form of 'post-politics' (where such quotidian interactions may be understood as acquiescence to a prevailing neoliberal system). Instead, we want to draw out the role of these sites as incubators, where modes of political participation are formulated and expressed within societies undergoing rapid political transformations. These processes of deliberation and interaction are founded upon the proximity of different actors, their intimacy, and the subsequent new performances of both self and collectivity. Such enactments may not always be progressive, the need to seek employment led the coffee shop, at times, to become sites for the accrual of individual social capital. But the experience of youth in these sites was not subsumed under this banner of neoliberal individualism; instead these demands were knowingly adopted and often contested. The more dominant imaginary for the coffee shop was the sanctuary, a site that provided the necessary space to deliberate ideas in a site that is valorised as outwith the social forces that shape both the public and private spheres.

The third conclusion relates to the role of civility to this discussion. We have been drawn to an interpretation of civility not as a stable identity form, nor as normative politics. Rather we are keen to think through civility as a disposition where accommodation of difference may be enacted without recourse to violence. Civility, in these terms, is an expression of intimacy-geopolitics, an embodied practice that is shaped by forces both distant and proximate. As suggested at the outset, this focus orientates attention not so much on the agents themselves, as the spaces between, orientating attention towards styles of respect and empathy. We share with others a concern for a revival of the coffee shop as a bourgeois public sphere, with all the attendant exclusions. We see the civility as a means through which to understand minimal moral obligations within specific material sites and imagined communities. Considering the empirical settings of this paper, this moral obligation is often framed in terms of a more hopeful politics of the future, where essential and embodied difference - whether race, religion or ethnicity - is confronted and resisted, replaced by inclusive visions of political life. It is these mundane sites of interaction and performance that suture together coffee, civility and subject formation. 


\section{Acknowledgements}

This paper draws on work conducted within the YouCitizen research project, funded by the European Research Council (ERC 295392). The paper was first presented at the Dilemmas of Civil Society workshop in March 2015, Emmanuel College Cambridge.

The authors are grateful to the participants for their feedback.

\section{References}

Amin, A. (2004). Regions Unbound: Towards a new politics of place. Geografiska Annaler B, 86(1), $33-44$.

Baillie Smith, M., \& Jenkins, K. (2011). Disconnections and exclusions: Professionalization, cosmopolitanism and (global?) civil society. Global Networks, 11(2), 160-179.

Bartolovich, C. (2000). Inventing London. In M. Hill, \& W. Montag (Eds.), Masses, classes and the public sphere (pp. 13-40). London and New York: Verso.

Belloni, R. (2001). Civil society and peacebuilding in Bosnia and Herzegovina. Journal of Peace Research, 38, 163-180.

Benhabib, S. (1995). The Pariah and her Shadow: Hannah Arendt's biography of Rahel Varnhagen. Political Theory, 23, 5-24.

Boyd, R. (2004). Uncivil society: The perils of pluralism and the making of modern Liberalism. Lanham, MD: Lexington Books.

Boyd, R. (2006). The value of civility? Urban Studies, 43, 863-878.

Boyd, R. (2015). Between grammar and style: Adam Smith and the (in)formality of civility and civil society. In Paper presented at Dilemmas of Civil Society Workshop. Emmanuel College Cambridge.

Bringa, T. (1995). Being Muslim the bosnian way: Identity and community in a central Bosnian village. Princeton: Princeton University Press.

Buire, C., \& Staeheli, L. A. (2017). Contesting the 'active'in active citizenship: Youth activism in Cape Town, South Africa. Space and Polity, 1-18. http://dx.doi.org/10.1080/13562576.2017.1339374.

Campbell, D. (1998). National deconstruction. Minnesota: Minnesota University Press.

Dean, J. (2001). Cybersalons and civil society: Rethinking the public sphere in transnational technoculture. Public Culture, 13, 243-265. 
Fagan, A. (2005). Taking stock of civil-society development in post-communist Europe: Evidence from the Czech Republic. Democratization, 12, 528-547.

Ferguson, J. (2015). Give a man a fish: Reflections on the new politics of distribution. Durham N.C.: Duke University Press.

Gregory, D. (2004). Colonial present. Malden: Blackwell Publishing.

Grigg, D. (2002). The worlds of tea and coffee: Patterns of consumption. GeoJournal, 57, 283-294.

Habermas, J. (1989). The structural transformation of the public sphere. Cambridge: Polity Press.

Harker, C., \& Martin, L. (2012). Familial relations: Spaces, subjects, and politics. Environment and Planning A, 44(4), 768-775.

Hearn, J. (2000). Aiding democracy? Donors and civil society in South Africa. Third World Quarterly, 21(5), 815-830.

Helms, E. (2010). The gender of coffee: Women and reconciliation initiatives in post-war Bosnia and Herzegovina. Focaal, 57, 17-32.

Hoare, M. A. (2007). The history of Bosnia: From the Middle Ages to the present day. London: Saqi Books.

Howell, P. (1993). Public space and the public sphere: Political theory and the historical geography of modernity. Environment and Planning D: Society and Space, 11(3), 303-322.

Jansen, S. (2015). Yearnings in the meantime: 'Normal lives' and the state in a Sarajevo apartment complex. Oxford, New York: Berghahn Books.

Jeffrey, A. (2007). The geopolitical framing of localized struggles: NGOs in Bosnia and Herzegovina. Development and Change, 38, 251-274.

Jeffrey, C. (2010). Timepass: Youth, class and the politics of waiting. Stanford: Stanford University Press.

Jeffrey, A. (2013). The improvised state: Sovereignty, performance and agency in Dayton Bosnia. Oxford: Wiley-Blackwell.

Jeffrey, A., \& Staeheli, L. (2016). Learning Citizenship: Civility, civil society and the possibilities of citizenship. In K. Kallio, S. Mills, \& T. Skelton (Eds.), Politics, citizenship and rights: Vol. 7. Geography of children and young people (pp. 481-496). London: Springer.

Kömeçoğlu, U. (2005). The publicness and sociabilities of the Ottoman coffeehouse. Javnost-The Public, 12,5-22.

Koopman, S. (2011). Alter-geopolitics: Other securities are happening. Geoforum, 42(3), 274-284. 
Landes, J. (1988). Women and the public sphere in the age of the French Revolution. Ithaca, NY: Cornell University Press.

Lange, B. (2011). Re-scaling governance in Berlin's creative economy. Culture Unbound: Journal of Current Cultural Research, 3(2), 187-208.

Laurier, E., \& Philo, C. (2006). Cold shoulders and napkins handed: Gestures of responsibility. Transactions of the Institute of British Geographers, 31, 193-20 .

Laurier, E., \& Philo, C. (2007). 'A parcel of muddling muckworms': Revisiting Habermas and the English coffee-houses. Social \& Cultural Geography, 8(2), 259-281.

Lemanski, C. (2004). A new apartheid? The spatial implications of fear of crime in Cape Town, South Africa. Environment and Urbanization, 16(2), 101-112.

Lippman, P. (2014). Bosnia-Herzegovina protests a response to post-war corruption, impoverishment. The Washington Report on Middle East Affairs, 33, 29-30.

Marshall, D. J., \& Staeheli, L. (2015). Mapping civil society with social network analysis: Methodological possibilities and limitations. Geoforum, 61, 56-66.

Marston, S. (1990). Who are 'the people'? Gender, citizenship, and the making of the American nation. Environment and Planning D: Society and Space, 8, 449-458.

McConnell, F. (2016). Rehearsing the state: The political practices of the Tibetan Government-InExile. Oxford: Wiley-Blackwell.

McEwan, C. (2003). Building a postcolonial archive? Gender, collective memory and citizenship in post-apartheid South Africa. Journal of Southern African Studies, 29(3), 739-757.

Mercer, C. (2002). NGOs, civil society and democratization: A critical review of the literature. Progress in Development Studies, 2,5-22.

Mitchell, D., Attoh, K., \& Staeheli, L. (2015). Whose city? What politics? Contentious and noncontentious spaces on Colorado's front range. Urban Studies, 52, 2633-2648.

Mouffe, C. (2005). The return of the Political. London: Verso.

Mountz, A., \& Hyndman, J. (2006). Feminist approaches to the global intimate. Women's Studies Quarterly, 34(1/2), 446-463.

Pain, R. (2014). Everyday terrorism: Connecting domestic violence and global terrorism. Progress in Human Geography, 38(4), 531-550.

Pain, R., \& Staeheli, L. (2014). Introduction: Intimacy-geopolitics and violence. Area, 46, 344-347. 
Pattman, R. (2007). Student identities, and researching these, in a newly 'racially'merged university in South Africa. Race Ethnicity and Education, 10(4), 473-492.

Posel, D., Casale, D., \& Vermaak, C. (2014). Job search and the measurement of unemployment in South Africa. South African Journal of Economics, 82, 66-80.

Said, E. (1978). Orientalism. London: Routledge and Kegan Paul.

Smith, M. D. (1996). The empire filters back: Consumption, production, and the politics of Starbucks coffee. Urban Geography, 17, 502-525.

Staeheli, L. A. (2008). Political geography: Difference, recognition, and the contested terrains of political claims-making. Progress in Human Geography, 32(4), 561-570.

Staeheli, L. A., \& Hammett, D. (2013). 'For the future of the nation': Citizenship, nation, and education in South Africa. Political Geography, 32, 32-41.

Toal, G., \& Dahlman, C. T. (2011). Bosnia remade. New York: Oxford University Press.

Wilson, R. (2001). The politics of truth and reconciliation in South Africa: Legitimizing the postapartheid state. Cambridge University Press.

Zizek, S. (2008). Violence: Six sideways reflections. New York: Picador. 